Article

\title{
Formation of Cl-Doped ZnO Thin Films by a Cathodic Electrodeposition for Use as a Window Layer in CIGS Solar Cells
}

\author{
Jianping Ao ${ }^{1}$, Rui Fu ${ }^{1}$, Ming-Jer Jeng ${ }^{2,3, *}$, Jinlian Bi ${ }^{1}$, Liyong Yao ${ }^{1}$, Shoushuai Gao ${ }^{1}$, \\ Guozhong Sun ${ }^{1}$, Qing He ${ }^{1}$, Zhiqiang Zhou ${ }^{1}$, Yun Sun ${ }^{1}$ and Liann-Be Chang ${ }^{2,3}$ \\ 1 Institute of Photoelectronic Thin Film Devices and Technology and Tianjin Key Laboratory of Thin film \\ Devices and Technology, Nankai University, Tianjin 300071, China; aojp@nankai.edu.cn (J.A.); \\ furui4321@163.com (R.F.); bijinlian815@126.com (J.B.); yaoliyong@yeah.net (L.Y.); \\ gaoshoushuai@yeah.net (S.G.); taigic@nankai.edu.cn (G.S.); Heqing27@nankai.edu.cn (Q.H.); \\ zhqzhou@126.com (Z.Z.); suny@nankai.edu.cn (Y.S.) \\ 2 Department of Electronic Engineering, Chang Gung University, Kweishan, Taoyuan 333, Taiwan; \\ liann@mail.cgu.edu.tw \\ 3 Department of Otolaryngology-Head and Neck Surgery, Chang Gung Memorial Hospital, Kweishan, \\ Taoyuan 333, Taiwan \\ * Correspondence: mjjeng@mail.cgu.edu.tw; Tel.: +886-3-211-8800 (ext. 3507); Fax: +886-3-211-8507
}

Received: 15 May 2018; Accepted: 28 May 2018; Published: 5 June 2018

\begin{abstract}
Zinc oxide films that are prepared by radio frequency (RF) sputtering are widely used as window layers in copper indium gallium diselenide (CIGS) solar cells. To reduce their production cost, the electrodeposition method for preparing $\mathrm{Cl}$-doped zinc oxide $(\mathrm{ZnO}: \mathrm{Cl})$, rather than sputtering, was studied. The electrodeposition parameters of injected current density and the $\mathrm{pH}$ of the electrolyte solution were studied. A moderate current density was used to yield high quality zinc oxides. The $\mathrm{pH}$ of the electrolyte greatly affected the formation of $\mathrm{ZnO}$ films. The $\mathrm{pH}$ value of the electrolyte that ensured that zinc oxides of high quality are obtained was close to seven. Electrodeposited $\mathrm{ZnO}: \mathrm{Cl}$ films had higher transmittance than $\mathrm{ZnO}: \mathrm{Al}$ films in the near-infrared region and so they can be used to improve the performance of solar cells. Our experiments revealed that the CIGS solar cells with electrodeposited $\mathrm{ZnO}: \mathrm{Cl}$ films as a window layer were slightly more efficient than those with sputtered $\mathrm{ZnO}: \mathrm{Al}$ films.
\end{abstract}

Keywords: Zinc oxide; RF sputtering; electrodeposition; Cl-doped zinc oxide (ZnO:Cl); cadmium sulfide; CIGS solar cells; transmittance

\section{Introduction}

Zinc oxides that are prepared by radio frequency (RF) sputtering are widely used as a window layer in copper indium gallium diselenide (CIGS) solar cells [1-3]. A good window layer must have high electrical conductivity and a low absorption coefficient at large wavelengths $[4,5]$, typically from infrared (IR) to ultraviolet (UV). To realize these properties, zinc oxides must be doped with another element [6]. This doping should be performed without any detrimental effect on the quality of the oxides. Cationic doping by the replacement of zinc with aluminum, indium, or silver has been commonly used to increase electrical conductivity [7-9], but anionic doping by the replacement of oxygen with fluorine, chlorine, or phosphor ions has not been widely used [10-13]. Chlorine may be a good dopant element for improving the physical properties of zinc oxide owing to its abundance, low cost, and valence difference of one electron with $\mathrm{O}$ [5]. $\mathrm{Cl}$ that is doped into $\mathrm{ZnO}$ can donate one electron to the free carriers and easily generate a conductive n-type material [14]. To reduce the cost of 
production, the electrodeposition method for preparing $\mathrm{Cl}$-doped zinc oxides ( $\mathrm{ZnO}: \mathrm{Cl}$ ), rather than sputtering, is proposed.

The key parameters of electrodeposition are injected current density, electrolyte concentration, $\mathrm{pH}$ value of the electrolyte solution, deposition time, and deposition temperature, among others. Our recent works [15] have shown that a high injected current density results in the fast deposition, the production of a $\mathrm{Zn}$ metal, and large surface roughness. A low current density results in a low deposition rate, a film of poor quality, and uniformity. A moderate current density can yield high-quality zinc oxides. $\mathrm{ZnO}: \mathrm{Cl}$ films of high quality cannot be obtained using a low or room electrodeposition temperature. A high electrodeposition temperature $\left(>70^{\circ} \mathrm{C}\right)$ results in an excessive deposition rate and poor film quality. Therefore, an electrodeposition temperature of $\sim 70{ }^{\circ} \mathrm{C}$ is favored. The concentration of the electrolyte solution is another important factor that influences the electrodeposition. When the $\mathrm{Cl}$-doped $\mathrm{ZnO}$ film is electrodeposited, the concentration of zinc chloride $\left(\mathrm{ZnCl}_{2}\right)$ in solution should be as low as possible. A high concentration of $\mathrm{ZnCl}_{2}$ can lead to the formation of $\mathrm{Zn}$ in the film. A low concentration of $\mathrm{ZnCl}_{2}$ is commonly used. Potassium chloride $(\mathrm{KCl})$ is the main source of $\mathrm{Cl}$ in the electrodeposition of a $\mathrm{ZnO}: \mathrm{Cl}$ film. $\mathrm{KCl}$ can increase the conductivity of the solution, facilitating the electrodeposition reaction. $\mathrm{ZnO}: \mathrm{Cl}$ films with good conductivity and high transmittance can be obtained at a $\mathrm{KCl}$ concentration of $0.2 \mathrm{M}$. However, the effect of $\mathrm{pH}$ of the electrolytes on the quality of $\mathrm{ZnO}: \mathrm{Cl}$ films has not yet been studied. Therefore, the performance of CIGS solar cells with a window layer of $\mathrm{Cl}$-doped $\mathrm{ZnO}$ films that are electrodeposited using the electrolyte with various $\mathrm{pH}$ values is studied herein.

\section{Experimental Section}

A $1 \mu \mathrm{m}$-thick molybdenum (Mo) layer was deposited on soda-lime glass by direct current (DC) magnetron sputtering. A CIGS absorber layer $(\sim 2 \mu \mathrm{m})$ was prepared by three-step evaporation. A CdS buffer layer with a thickness of 50-60 $\mathrm{nm}$ was prepared by chemical bath deposition (CBD). $\mathrm{Cl}$-doped $\mathrm{ZnO}$ was grown on the stack-layered substrate of glass/Mo/CIGS/CdS in a conventional three-electrode system using a potentiostat. The working, counter, and reference electrodes were glass/Mo/CIGS/CdS, a Zn foil electrode, and a saturated calomel electrode (SCE), respectively. The electrolyte was a mixed solution of $5 \mathrm{mMZnCl}_{2}$ and $0.2 \mathrm{M} \mathrm{KCl}$. The $\mathrm{pH}$ value of the electrolyte solution was adjusted by adding low concentrations of hydrogen chloride $(\mathrm{HCl})$ and ammonia. Oxygen gas was continuously supplied to the electrolyte and the electrolyte temperature was kept at $70{ }^{\circ} \mathrm{C}$ during electrodeposition. A moderate current density of $0.2 \mathrm{~mA} / \mathrm{cm}^{2}$ yielded zinc oxides of good quality at a deposition rate of $\sim 7 \mathrm{~nm} / \mathrm{min}$. The chlorine concentration of $1-2 \%$ in $\mathrm{ZnO}: \mathrm{Cl}$ films was determined by an energy dispersive spectroscopy (EDS) measurement. A Ni/Al metal grid was deposited on glass/Mo/CIGS/CdS/ZnO:Cl by electron-beam evaporation. CIGS solar cells that contained a window layer of $\mathrm{ZnO}: \mathrm{Cl}$ film were fabricated. The active area of each of these CIGS solar cells was $0.358 \mathrm{~cm}^{2}$.

The structural properties of the films were analyzed using a Philips X'pert PROX-ray diffractometer (Amsterdam, Netherlands) with $\mathrm{Cu} \mathrm{K \alpha}$ as the radiation source. Their surface morphology was observed using a scanning electron microscope (SEM, JEOL JSM-6700, Tokyo, Japan) with energy dispersive spectroscopy (EDS). Multiple UV-vis transmittance spectra were recorded using a Shimadzu UV-1800 (Kyoto, Japan) spectrophotometer. The current-voltage (J-V) characteristics of the CIGS solar cells were obtained using a solar simulator under the standard AM1.5 spectrum with an illumination intensity of $1000 \mathrm{~W} / \mathrm{m}^{2}$ at room temperature. The light intensity of the solar simulator was calibrated using a standard monocrystalline Si reference solar cell.

\section{Results}

Figure 1 plots the cyclic voltammetric $(\mathrm{CV})$ curves of $\mathrm{Zn}^{2+}$ ions in aqueous solutions with a $\mathrm{pH}$ value of 6.5. The electrolytes mentioned above were used to electrodeposit $\mathrm{Cl}$-doped $\mathrm{ZnO}$ films on the stack-layered substrate of the glass/Mo/CIGS/CdS structure. The applied voltage was swept 
from -0.2 to $-3 \mathrm{~V}$ and then swept back to $-0.2 \mathrm{~V}$. The inset in Figure 1 is a magnification of the curve around $-1.2 \mathrm{~V}$ for the forward scan. The scanning rate was maintained at $0.02 \mathrm{~V} / \mathrm{s}$ as the $\mathrm{CV}$ curve measurements were made. For the forward scan, the reduction reaction at $-1.1 \mathrm{~V}$ reduced oxygen molecules to hydroxide ions (Reaction 1). When the applied voltage was more negative than $-1.3 \mathrm{~V}$, the cathodic current of the samples in the electrolyte increased, corresponding to the reduction of $\mathrm{Zn}^{2+}$ ions in the solution to $\mathrm{Zn}$ (Reaction 2). As the applied voltage was swept backward, the oxidation reaction at $-0.8 \mathrm{~V}$ oxidized $\mathrm{Zn}$ to $\mathrm{Zn}^{2+}$ (Reaction 3). In the reaction of $\mathrm{ZnO}$ at the cathodic electrode, oxygen molecules in the electrolyte gained two electrons, forming hydroxide ions (Reaction 1). The hydroxide ions reacted with $\mathrm{Zn}^{2+}$ ions to form zinc hydroxide $\left(\mathrm{Zn}(\mathrm{OH})_{2}\right)$ (Reaction 4$)$. At $70{ }^{\circ} \mathrm{C}, \mathrm{Zn}(\mathrm{OH})_{2}$ dehydrated spontaneously to $\mathrm{ZnO}$ and water (Reaction 5). Therefore, the overall reaction at the cathodic electrode was formulated as Reaction 6. From the CV measurements, a very small electrodepositing current was detrimental to the oxidation and reduction reaction when the applied voltage at the cathodic electrode is less negative than $-1.1 \mathrm{~V}$. In that case, the formed $\mathrm{ZnO}$ film was non-uniform. However, a very large electrodepositing current caused the formation of $\mathrm{Zn}$. The formation of $\mathrm{Zn}$ in the $\mathrm{ZnO}$ films seriously degraded the oxide quality. Therefore, choosing the correct applied voltage for electrodeposition is important for obtaining a high-quality $\mathrm{ZnO}$ film.

$$
\begin{gathered}
\frac{1}{2} \mathrm{O}_{2}+\mathrm{H}_{2} \mathrm{O}+2 \mathrm{e}^{-} \rightarrow 2 \mathrm{OH}^{-} \\
\mathrm{Zn}^{2+}+2 \mathrm{e}^{-} \rightarrow \mathrm{Zn} \\
\mathrm{Zn}-2 \mathrm{e}^{-} \rightarrow \mathrm{Zn}^{2+} \\
\mathrm{Zn}^{2+}+2 \mathrm{OH}^{-} \rightarrow \mathrm{Zn}(\mathrm{OH})_{2} \\
\mathrm{Zn}(\mathrm{OH})_{2} \rightarrow \mathrm{ZnO}+\mathrm{H}_{2} \mathrm{O} \\
\mathrm{Zn}^{2+}+\frac{1}{2} \mathrm{O}_{2}+2 \mathrm{e}^{-} \rightarrow \mathrm{ZnO}
\end{gathered}
$$

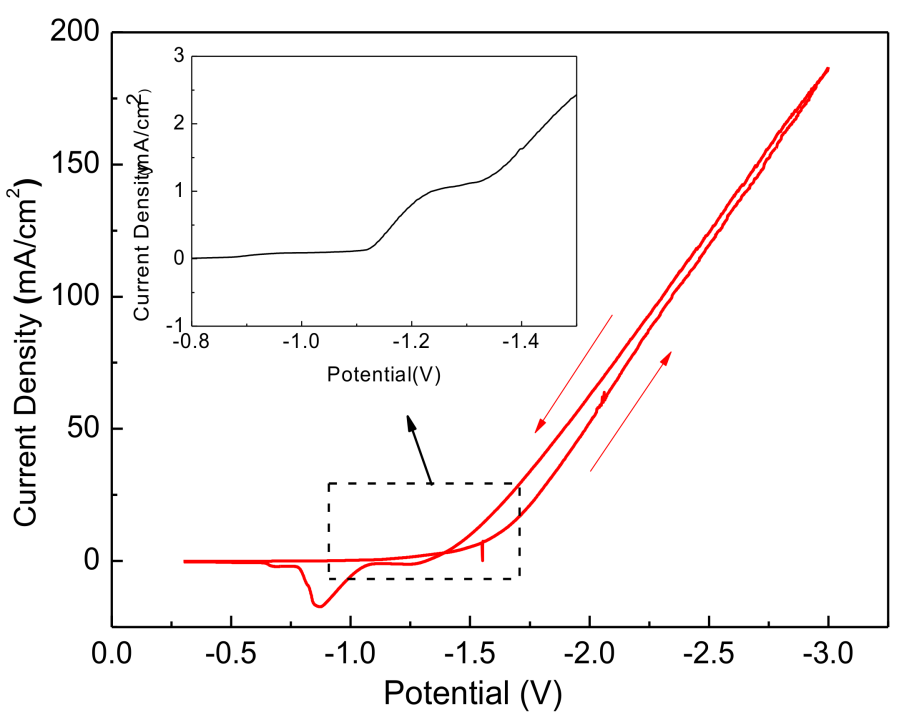

Figure 1. The $\mathrm{CV}$ curves of $\mathrm{Zn}^{2+}$ ions in aqueous solutions with a $\mathrm{pH}$ value of 6.5.

The growth of $\mathrm{ZnO}$ was affected by the $\mathrm{pH}$ value of the electrolytes. When the $\mathrm{pH}$ of the electrolytes was too low, the reaction products of $\mathrm{Zn}(\mathrm{OH})_{2}$ in reaction 4 were consumed, and the formed $\mathrm{ZnO}$ dissolved again. The amount of $\mathrm{ZnO}$ did not increase. Simultaneously, $\mathrm{CdS}$ film dissolves, negatively affecting device performance. However, an excessive $\mathrm{pH}$ value promoted the hydrolysis of 
$\mathrm{ZnCl}_{2}$. The $\mathrm{Zn}(\mathrm{OH})_{2}$ in the electrolyte solution suppressed reaction 4 , so the amount of the $\mathrm{ZnO}$ that was produced was insufficient for reaction 5 owing to the hydrolyzability of $\mathrm{ZnCl}_{2}$. In the preparation of the electrolytes, a floc was likely to appear in solution. The $\mathrm{pH}$ of the electrolyte solution must be adjusted to ensure that the solution is clear. A low concentration of $\mathrm{HCl}$ was dropped into the solution. When the floc in the solution disappeared and the solution became clear, the $\mathrm{pH}$ of the solution was approximately 6.4. The solutions were rendered weakly acidic or weakly alkaline by dropping low concentrations of $\mathrm{HCl}$ or ammonia, respectively, into the solution.

To find a suitable electrodepositing current for preparing high-quality $\mathrm{ZnO}$ films, Figure 2a-d show the X-ray diffraction (XRD) patterns of $\mathrm{Cl}$-doped $\mathrm{ZnO}$ films that were electrodeposited with current densities of $0.05,0.1,0.2$, and $0.4 \mathrm{~mA} / \mathrm{cm}^{2}$, respectively. The $\mathrm{Cl}$-doped $\mathrm{ZnO}$ films yielded three strong peaks that were indexed as (100), (002), and (101), as well as a weak peak that was indexed as (102), indicating a hexagonal wurtzite structure. A slight shift in these peaks toward lower diffraction angles was associated with the $\mathrm{Cl}$-doped $\mathrm{ZnO}$ films, indicating that chlorine was incorporated into the crystal structure, expanding the $\mathrm{ZnO}$ crystal lattice. At a low current density in Figure 2a, very weak peak intensities were obtained, revealing that $\mathrm{Cl}$-doped $\mathrm{ZnO}$ films are very thin and have very poor crystallinity. At a moderate current density, as seen in Figure $2 b, c$, the peaks were very strong, and no additional peaks that correspond to $\mathrm{Zn}, \mathrm{Cl}$, or any other impurity were visible. $\mathrm{Cl}$-doped $\mathrm{ZnO}$ films exhibited good crystallinity. At a high current density, as shown in Figure 2d, the peak intensities were strong, but weaker than those in Figure 2c. Three metal Zn peaks, indexed as (100), (002), and (101) were also obtained, revealing that $\mathrm{Zn}^{2+}$ ions at the cathodic surface were reduced to $\mathrm{Zn}$ and then incorporated into $\mathrm{Cl}$-doped $\mathrm{ZnO}$ films. The formation of $\mathrm{Zn}$ in $\mathrm{Cl}$-doped $\mathrm{ZnO}$ films seriously degraded the oxide quality. Therefore, as indicated above, the current density of $0.2 \mathrm{~mA} / \mathrm{cm}^{2}$ was suitable for the electrodeposition of $\mathrm{Cl}$-doped $\mathrm{ZnO}$ films on the stack-layered substrate of glass/Mo/CIGS/CdS.

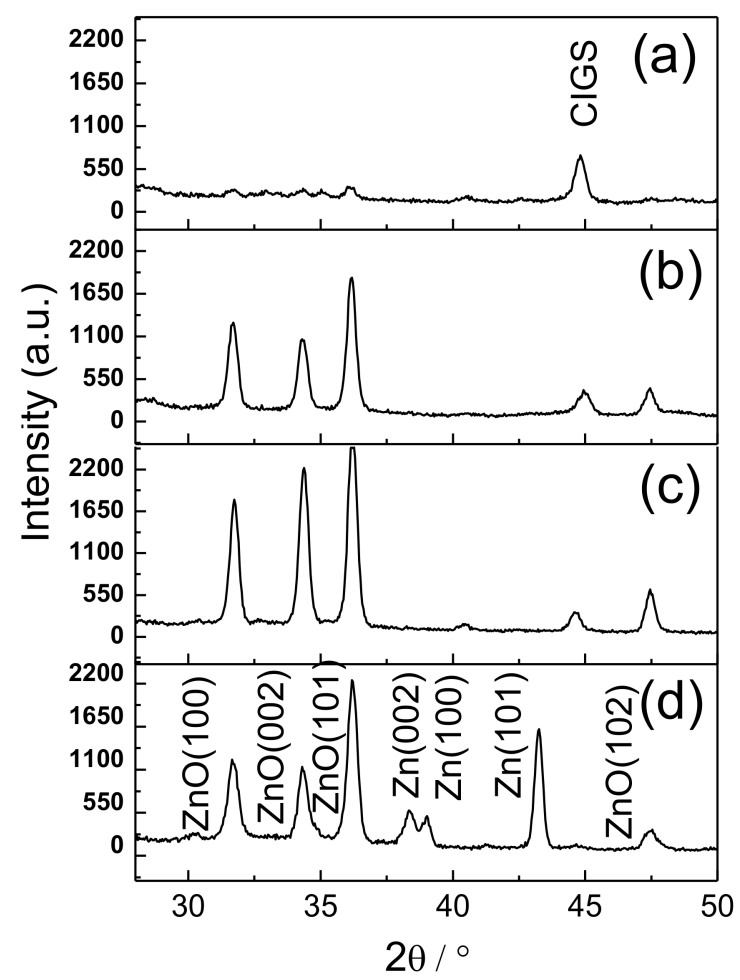

Figure 2. X-ray diffraction (XRD) patterns of $\mathrm{Cl}$-doped $\mathrm{ZnO}$ films that were electrodeposited with current densities of (a) 0.05, (b) 0.1, (c) 0.2 , and (d) $0.4 \mathrm{~mA} / \mathrm{cm}^{2}$.

As is well known, $\mathrm{ZnO}$ and $\mathrm{CdS}$ thin films dissolve in strong acid, detrimentally affecting the performance of CIGS solar cells [16]. Hydrogen bubbles are easily generated in the electrolyte when 
applying a strong acid owing to the presence of excess hydrogen ions. These bubbles cause the oxide to be of poor quality. Therefore, a weakly acidic electrolyte was used to study the formation of Cl-doped $\mathrm{ZnO}$ films. Figure 3a-d show the XRD patterns of $\mathrm{Cl}$-doped $\mathrm{ZnO}$ films that were electrodeposited using the electrolytes with $\mathrm{pH}$ values of 7.1, 6.4, 5.2, and 4.2, respectively. The thickness of Cl-doped $\mathrm{ZnO}$ films was controlled at $\sim 500 \mathrm{~nm}$ by adjusting their deposition time, because growth rate varied with $\mathrm{pH}$ values. Clearly, the $\mathrm{Cl}$-doped $\mathrm{ZnO}$ films with three strong peaks indexed as (100), (002), and (101), and a weak peak indexed as (102), when obtained using electrolytes with various $\mathrm{pH}$ values, had a hexagonal wurtzite structure. Interestingly, it was observed that $\mathrm{Cl}$-doped $\mathrm{ZnO}$ films, which were prepared by the electrolytes with $\mathrm{pH}$ values of 7.1 and 4.2 , have a dominant peak of $(002)$, indicating that these $\mathrm{ZnO}: \mathrm{Cl}$ films grew preferably in [0001] direction, perpendicular to the substrate. However, the $\mathrm{Cl}$-doped $\mathrm{ZnO}$ films, which were prepared by the electrolytes with $\mathrm{pH}$ values of 6.4 and 5.2, have a dominant (101) peak, and two peaks ((100) and (002)) of moderate intensity. The dominant (101) peak indicates that the $\mathrm{ZnO}: \mathrm{Cl}$ films may have a random growth direction, independent of the substrates in these samples.

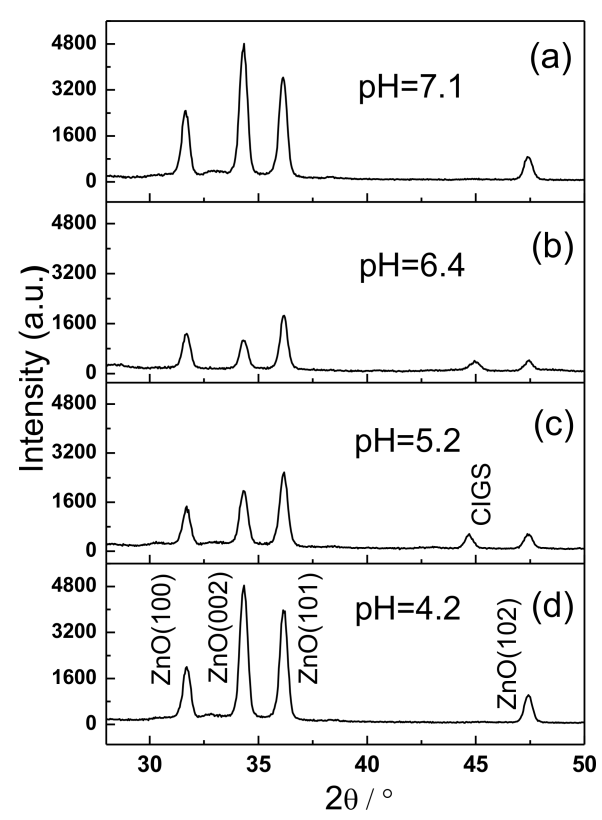

Figure 3. The XRD patterns of $\mathrm{Cl}$-doped $\mathrm{ZnO}$ films that were electrodeposited using electrolytes with four $\mathrm{pH}$ values of (a) 7.1, (b) 6.4, (c) 5.2, and (d) 4.2 .

The surface morphologies of the $\mathrm{Cl}$-doped $\mathrm{ZnO}$ thin films that were obtained by electrodeposition using solutions with various $\mathrm{pH}$ values were studied. Figure 4 shows surface images of $\mathrm{Cl}$-doped $\mathrm{ZnO}$ films that were electrodeposited using electrolytes with $\mathrm{pH}$ values of 4.2, 5.2, 6.4, and 7.1. As is clearly seen in these figures, the surface morphology had a grained structure and the grains had hexagonal shapes. The films that were deposited at $\mathrm{pH}=7.1$ exhibited relatively high crystallization, a clear hexagonal columnar structure, obvious grain boundaries, and few clusters. The films that were deposited at $\mathrm{pH}=5.2$ and $\mathrm{pH}=6.4$ had smaller grains, a more compact arrangement of grains, and a smooth grain boundary. At a $\mathrm{pH}$ value of 4.2 , the grain size of the obtained films was larger and the grain boundaries were clear. However, the films contained more clusters, with a disordered arrangement, between the structure and the grains. The growth direction was not uniform. The different growth orientations of the $\mathrm{ZnO}$ thin films may have arisen from the various mechanisms of formation under various $\mathrm{pH}$ conditions.

Figure 5 plots the current-voltage curve of CIGS solar cells with a window layer of Cl-doped $\mathrm{ZnO}$ films that were electrodeposited using the electrolytes with the four $\mathrm{pH}$ values. The cell with $\mathrm{Cl}$-doped $\mathrm{ZnO}$ films that was prepared using the electrolytes with a $\mathrm{pH}$ value of 7.1 had the highest 
solar efficiency. In contrast, $\mathrm{pH}=4.2$ yielded the lowest efficiency. The morphology of the $\mathrm{ZnO}: \mathrm{Cl}$ films that were obtained at $\mathrm{pH}=7.1$ had a hexagonal columnar structure with dense grains of moderate size and a clear orientation. The hexagonal columnar structure of the $\mathrm{ZnO}: \mathrm{Cl}$ film that was obtained at $\mathrm{pH}=4.2$ is not obvious. The grains were larger and their arrangement was irregular, indicating that the surface morphology of electrodeposited $\mathrm{ZnO}: \mathrm{Cl}$ films greatly affected the performance of the cell in which they are used. Table 1 presents the detailed performance parameters of CIGS solar cells with a window layer of $\mathrm{Cl}$-doped $\mathrm{ZnO}$ films that are electrodeposited using electrolytes with four $\mathrm{pH}$ values.
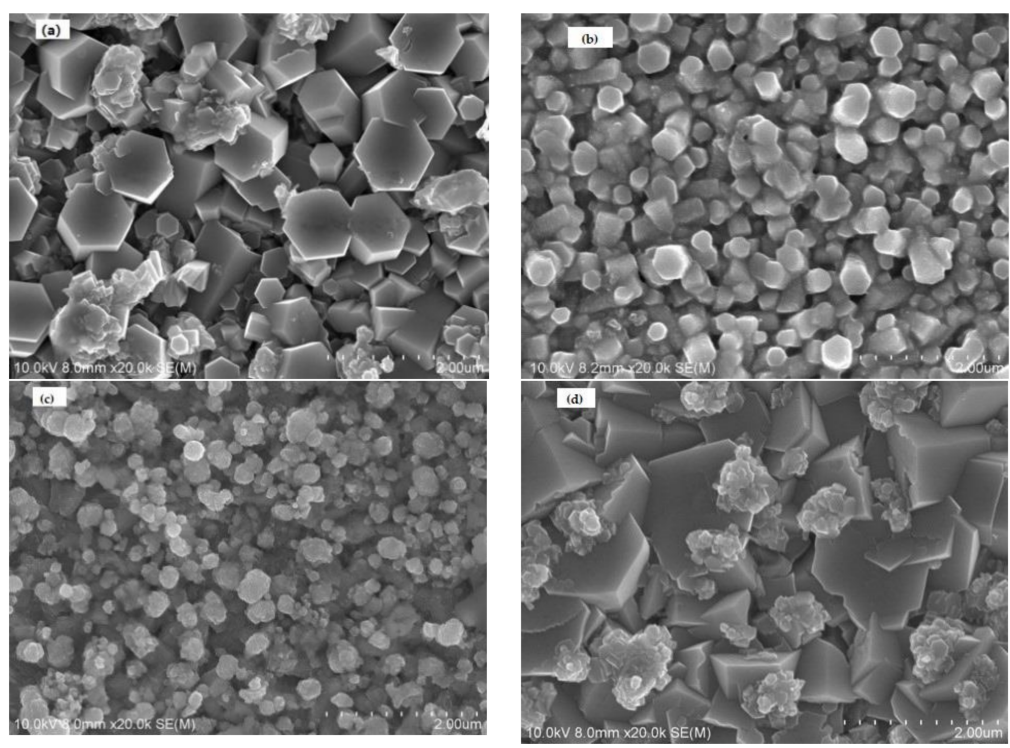

Figure 4. The surface SEM images of Cl-doped $\mathrm{ZnO}$ films that were electrodeposited using electrolytes with four $\mathrm{pH}$ values of (a) 7.1,(b) 6.4, (c) 5.2, and (d) 4.2.

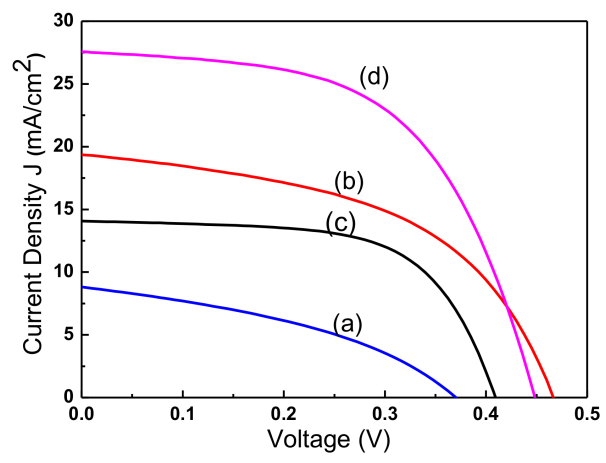

Figure 5. The current-voltage curves of CIGS solar cells with a window layer of Cl-doped ZnO films that were electrodeposited using electrolytes with four $\mathrm{pH}$ values of (a) 4.2, (b) 5.2, (c) 6.4, and (d) 7.1.

Table 1. Performance parameters of CIGS solar cells with Cl-doped $\mathrm{ZnO}$ films that were prepared by various $\mathrm{pH}$ values.

\begin{tabular}{ccccc}
\hline $\mathbf{p H}$ & Voc $(\mathbf{m V})$ & Jsc $\left(\mathbf{m A} / \mathbf{c m}^{\mathbf{2}}\right)$ & $\mathbf{F F}(\mathbf{\%})$ & $\mathbf{H ~ ( \% )}$ \\
\hline 4.2 & 370 & 8.18 & 38.98 & 2.27 \\
5.2 & 467 & 19.35 & 50.21 & 4.54 \\
6.4 & 409 & 14.07 & 62.70 & 3.61 \\
7.1 & 448 & 27.56 & 56.12 & 6.93 \\
\hline
\end{tabular}


Figure 6 plots the transmittance of sputtered Al-doped $\mathrm{ZnO}(\mathrm{ZnO}: \mathrm{Al})$ and electrodeposited $\mathrm{Cl}$-doped $\mathrm{ZnO}$ thin films. The thicknesses of Al-doped and Cl-doped $\mathrm{ZnO}$ films are 500 and $550 \mathrm{~nm}$, respectively. The transmittance of $\mathrm{ZnO}: \mathrm{Cl}$ films increased from $50 \%$ to $80 \%$ as the wavelength increased from 400 to $800 \mathrm{~nm}$, and remained at $~ 80 \%$ for wavelengths ranging from 800 to $1400 \mathrm{~nm}$. The transmittance began to decline when the wavelength reached $1400 \mathrm{~nm}$. A sputtered Al-doped zinc oxide was prepared for comparison. The sputtered $\mathrm{ZnO}$ :Al films had a higher transparency than the electrodeposited zinc oxide for wavelengths of 400-800 $\mathrm{nm}$. However, the transmittance of the sputtered $\mathrm{ZnO}: \mathrm{Al}$ films was much lower in the near-infrared region $(>800 \mathrm{~nm})$. The electrodeposited zinc oxide with Cl-doping had high transmittance in the near-infrared region $(>800 \mathrm{~nm})$. Therefore, CIGS solar cells with a window layer of $\mathrm{ZnO}: \mathrm{Cl}$ films exhibit better light absorption in the near-infrared region than do $\mathrm{ZnO}: \mathrm{Al}$ films. Generally, the resistivity of electrodeposited $\mathrm{ZnO}: \mathrm{Cl}$ films was higher than those of the sputtered one. However, the transmittance property of $\mathrm{ZnO}: \mathrm{Cl}$ films is better than that of sputtered $\mathrm{ZnO}: \mathrm{Al}$ films. A trade-off between the electrical performance and the transparency of the layer needs to be made [17]. Figure 7 plots the current-voltage curve of CIGS solar cells with a window layer of sputtered $\mathrm{ZnO}: \mathrm{Al}$ and electrodeposited $\mathrm{ZnO}: \mathrm{Cl}$ films. The efficiency of CIGS solar cells with electrodeposited $\mathrm{ZnO}: \mathrm{Cl}$ films is slightly higher than that of those with sputtered $\mathrm{ZnO}: \mathrm{Al}$ films. The low open-circuit voltage of sputtered zinc oxide might have been caused by sputtering damage, which is the creation of recombination centers. The slightly higher short-circuit current in the electrodeposited $\mathrm{ZnO}: \mathrm{Cl}$ film may have been a result of high absorption in CIGS films in the near-infrared region.

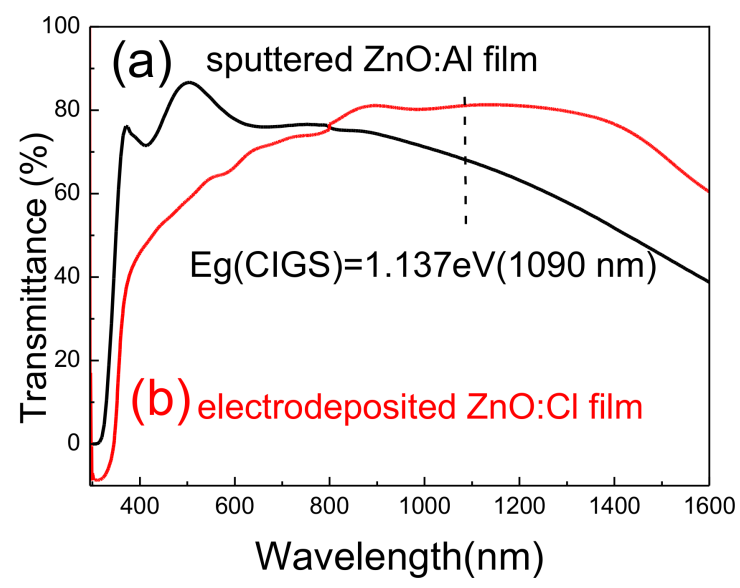

Figure 6. The transmittance of (a) sputtered $\mathrm{ZnO}: \mathrm{Al}$, and (b) electrodeposited $\mathrm{ZnO}: \mathrm{Cl}$ films.

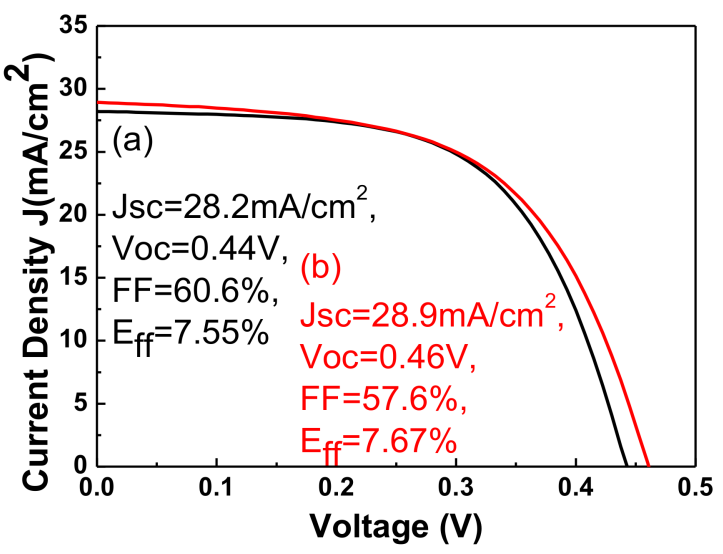

Figure 7. The current-voltage (CV) curves of CIGS solar cells with the window layer of (a) sputtered $\mathrm{ZnO}: \mathrm{Al}$, and (b) electrodeposited $\mathrm{ZnO}: \mathrm{Cl}$ films. 


\section{Conclusions}

The electrodeposition parameters of injected current density and the $\mathrm{pH}$ value of the electrolyte solution that are used in preparing $\mathrm{Cl}$-doped $\mathrm{ZnO}$ films were studied. The $\mathrm{XRD}$ results indicated that $\mathrm{Cl}$-doped $\mathrm{ZnO}$ films were very thin and had very poor crystallinity at a low current density of $0.005 \mathrm{~mA} / \mathrm{cm}^{2}$, and high crystallinity at a moderate current density of $0.2 \mathrm{~mA} / \mathrm{cm}^{2}$. The formation of $\mathrm{Zn}$ in $\mathrm{Cl}$-doped $\mathrm{ZnO}$ films at a high current density of $0.4 \mathrm{~mA} / \mathrm{cm}^{2}$ seriously degraded the quality of the oxide. The Cl-doped $\mathrm{ZnO}$ films with three strong peaks indexed as (100), (002), and (101), and a weak peak indexed as (102) meant they had a hexagonal wurtzite structure. The dominant peak of (002) from Cl-doped $\mathrm{ZnO}$ films that were prepared using electrolytes with $\mathrm{pH}$ values of 7.1 and 4.2 showed that in most of the $\mathrm{ZnO}$ films, the [0001] direction was perpendicular to the substrate. In contrast, the XRD patterns of the $\mathrm{Cl}$-doped $\mathrm{ZnO}$ films that were prepared using electrolytes with $\mathrm{pH}$ values of 6.4 and 5.2 showed the (101) peak as dominant, and two peaks ((100) and (002) peaks) of moderate intensity that could have arisen because of the random direction relative to the substrates in these samples. The sputtered $\mathrm{ZnO}: \mathrm{Al}$ films had a greater transparency to wavelengths of $400-800 \mathrm{~nm}$ than does the electrodeposited $\mathrm{ZnO}: \mathrm{Cl}$. However, the transmittance of sputtered $\mathrm{ZnO}: \mathrm{Al}$ films was much lower in the near-infrared region $(>800 \mathrm{~nm})$. Therefore, the electrodeposited $\mathrm{ZnO}: \mathrm{Cl}$ films had a higher transmittance than the $\mathrm{ZnO}: \mathrm{Al}$ films in the near-infrared region. The experimental results herein indicated that CIGS solar cells with electrodeposited $\mathrm{ZnO}: \mathrm{Cl}$ films as the window layer were slightly more efficient than those with sputtered $\mathrm{ZnO}$ :Al films.

Author Contributions: J.A. carried out the design of electrodeposition and coordination. R.F. carried out the electrodeposition of $\mathrm{Cl}$-doped $\mathrm{ZnO}$ films. M.-J.J. carried out the discussion of experimental results and drafted the manuscript. J.B. and L.Y. carried out the Mo deposition by sputtering. S.G. carried out $\mathrm{ZnO}$ and $\mathrm{ZnO}$ :Al depositions by sputtering. G.S., Q.H., and Z.Z. carried out the CdS deposition by CBD and the performance measurement of solar cells. Y.S. participated in the discussion of experimental results and coordination. L.-B.C. participated in the discussion of experimental results.

Funding: This work was supported by the National Natural Science Foundation of China (61274082), and Tianjin Natural Science Foundation of Key Projects (16JCZDJC30700), Chang Gung University, Chang Gung Memorial Hospital, and the Ministry of Science and Technology, Republic of China (the Contract No. NERPD2G0251, BMRPA52, and MOST 106-2221-E-182-046.), and YangFan Innovative and Entrepreneurial Research Team Project (2014YT02N037).

Conflicts of Interest: The authors declare no conflict of interest.

\section{References}

1. Chopra, K.L.; Paulson, P.D.; Dutta, V. Thin-film solar cells: An overview. Prog. Photovolt. Res. Appl. 2004, 12, 69-92. [CrossRef]

2. Repins, I.; Contreras, M.A.; Egaas, B.; DeHart, C.; Scharf, J.; Perkins, C.L.; To, B.; Noufi, R. 19.9\%-efficient $\mathrm{ZnO} / \mathrm{CdS} / \mathrm{CuInGaSe}_{2}$ solar cell with $81.2 \%$ fill factor. Prog. Photovol. Res. Appl. 2008, 16, 235-239. [CrossRef]

3. Jackson, P.; Hariskos, D.; Wuerz, R.; Kiowski, O.; Bauer, A.; Friedlmeier, T.M.; Powalla, M. Properties of $\mathrm{Cu}(\mathrm{In}, \mathrm{Ga}) \mathrm{Se}_{2}$ solar cells with new record efficiencies up to 21.7\%. Phys. Status Solidi Res. Lett. 2015, 9, $28-31$. [CrossRef]

4. Ellmer, K.; Klein, A.; Rech, B. Transparent Conductive Zinc Oxide: Basics and Applications in Thin Film Solar Cells; Springer: Berlin, Germany, 2007.

5. Rousset, J.; Saucedo, E.; Herz, K.; Lincot, D. High efficiency CIGS-based solar cells with electrodeposited $\mathrm{ZnO}: \mathrm{Cl}$ as transparent conducting oxide front contact. Prog. Photovolt. Res. Appl. 2011, 19, 537-546. [CrossRef]

6. Yim, K.; Lee, J.; Lee, D.; Lee, M.; Cho, E.; Lee, H.S.; Nahm, H.H.; Han, S. Property database for singleelement doping in $\mathrm{ZnO}$ obtained by automated first-principles calculation. Sci. Rep. 2017, 7, 4090. [CrossRef] [PubMed]

7. Fay, S.; Steinhauser, J.; Oliveira, N.; Vallat-Sauvain, E.; Ballif, C. Opto-electronic properties of rough LP-CVD ZnO: B for use as TCO in thin-film silicon solar cells. Thin Solid Films 2007, 515, 8558-8561. [CrossRef]

8. Kemell, M.; Dartigues, F.; Ritala, M.; Leskela, M. Electrochemical preparation of In and Al doped ZnO thin films for CuInSe 2 solar cells. Thin Solid Films 2003, 434, 20-23. [CrossRef] 
9. Ma, Q.B.; Ye, Z.; He, H.; Wang, J.; Zhu, L.; Zhang, Y.; Zhao, B. Structural, electrical, and optical properties of transparent conductive ZnO:Ga films prepared by DC reactive magnetron sputtering. J. Cryst. Growth 2007, 304, 64-68. [CrossRef]

10. $\mathrm{Hu}, \mathrm{J} . ;$ Gordon, R.G. Textured fluorine-doped $\mathrm{ZnO}$ films by atmospheric pressure chemical vapor deposition and their use in amorphous silicon solar cells. Sol. Cells 1991, 30, 437-450. [CrossRef]

11. Cui, J.B.; Soo, Y.C.; Chen, T.P.; Gibson, U.J. Low-temperature growth and characterization of Cl-Doped ZnO nanowire arrays. J. Phys. Chem. C 2008, 112, 4475-4479. [CrossRef]

12. Tchelidze, T.; Chikoidze, E.; Gorochov, O.; Galtier, O. Perspectives of chlorine doping of ZnO. Thin Solid Films 2007, 515, 8744-8747. [CrossRef]

13. Chikoidze, E.; Nolan, M.; Modreanu, M.; Sallet, V.; Galtier, P. Effect of chlorine doping on electrical and optical properties of ZnO thin films. Thin Solid Films 2008, 516, 8146-8149. [CrossRef]

14. Peulon, S.; Lincot, D. Cathodic electrodeposition from aqueous solution of dense or open-structured zinc oxide films. Adv. Mater. 1996, 8, 166-170. [CrossRef]

15. Fu, R. The Research of Electrodeposition of CIGS Window Layer ZnO: Cl Thin Film. Master Thesis, Nankai University, Tianjin, China, May 2013.

16. Hayes, T.M.; Lurio, L.B.; Persans, P.D. Growth and dissolution of CdS nanoparticles in glass. J. Phys. Condens. Matter 2001, 13, 425-432. [CrossRef]

17. Tsin, F.; Venerosy, A.; Vidal, J.; Collin, S.; Clatot, J.; Lombez, L.; Paire, M.; Borensztajn, S.; Broussillou, C.; Grand, P.P.; et al. Electrodeposition of $\mathrm{ZnO}$ window layerfor an all-atmospheric fabricationprocess of chalcogenide solar cell. Sci. Rep. 2015, 5, 8961.

(C) 2018 by the authors. Licensee MDPI, Basel, Switzerland. This article is an open access article distributed under the terms and conditions of the Creative Commons Attribution (CC BY) license (http:/ / creativecommons.org/licenses/by/4.0/). 